Zeszyty Naukowe Szkoły Głównej Gospodarstwa Wiejskiego w Warszawie

Problemy Rolnictwa Światowego tom 18 (XXXIII), zeszyt 4, 2018: 38-49

DOI: 10.22630/PRS.2018.18.4.95

Dorota Pasińska $^{1}$

Instytut Ekonomiki Rolnictwa i Gospodarki Żywnościowej - Państwowy Instytut

Badawczy w Warszawie

\title{
Handel zagraniczny produktami kurzymi w latach 2012-2017
}

\section{Polish Foreign Trade in Chicken Products from 2012-2017}

\begin{abstract}
Synopsis. Głównym celem artykułu jest przedstawienie polskiego rynku kurzego w latach 2012-2017 w kontekście zmian w handlu zagranicznym produktami kurzymi. W celu weryfikacji hipotezy wykorzystano metody statystyki opisowej (analizę porównawczą w czasie, analizę struktury, liniową funkcję trendu). W badanym okresie obserwuje się tendencję do powiększania się dodatniego salda obrotów handlowych mięsem, podrobami i przetworami kurzymi, natomiast saldo drobiem żywym było ujemne. W latach 2012-2017 przy znacznym wzroście pogłowia kur (oprócz niosek), wystapił ponad 58\% wzrost ich ubojów oraz ponad dwukrotnie zwiększył się eksport produktów kurzych (drób kurzy żywy, mięso, podroby i przetwory). W eksporcie i w spożyciu dominują produkty kurze, a na drugim miejscu są produkty indycze. Produkcja żywca kurzego jest bardzo skoncentrowana.
\end{abstract}

Słowa kluczowe: polski rynek żywca kurzego, tuszka, handel zagraniczny, pogłowie kur, produkcja żywca kurzego, cena

\begin{abstract}
The main goal of the article is to present the Polish chicken market in 2012-2017 in the context of changes in foreign trade in chicken products. In order to achieve the goal, the methods of descriptive statistics (comparative analysis over time, structure analysis, linear trend function) were used. In the analyzed period, there is a tendency to increase the positive balance of trade in meat, offal and chicken preserves, while the balance of live poultry was negative. In the years 2012-2017, with a significant increase in the stock of chickens (except laying hens), there was over 58\% increase in their slaughter, and the export of chicken products (live hens, meat, offal, preserves) increased more than twice. In export and consumption, chicken products dominate, followed by turkey products. The production of live chicken is very concentrated.
\end{abstract}

Key words: Polish chicken market, carcass, foreign trade, chicken stock, chicken production, price

JEL Classification: Q11, Q13, Q17, Q18

\section{Wprowadzenie}

Polska jest największym producentem żywca kurzego w UE od 2014 r. Produkcja mięsa kurzego w UE jest bardzo skoncentrowana, około dwie trzecie tej produkcji dostarczają Polska, Wielka Brytania, Hiszpania, Francja, Holandia i Włochy (Slaughtering...., 2018).

W latach 2012-2017 zaszły znaczne zmiany na rynku produktów kurzych, zwiększała się jego produkcja, eksport i import (GUS c, 2013-2018, dane MF). Mięso kurze było tańsze niż np. mięso wołowe i jest łatwiejsze w obróbce kulinarnej niż mięso wołowe. Sprzyjało to wzrostowi jego spożycia (z 26,1 kg/mieszkańca w 2012 r. do 29,2 kg/ mieszkańca w 2016 r.) (GUS b 2013, 2017). Instytut Ekonomiki Rolnictwa i Gospodarki

\footnotetext{
${ }^{1}$ dr, Instytut Ekonomiki Rolnictwa i Gospodarki Żywnościowej - PIB, ul. Świętokrzyska 20, 00-002 Warszawa; e-mail: dorota.pasinska@ierigz.waw.pl; http://orcid.org/0000-0003-4363-9202
} 
Żywnościowej - PIB przewiduje, że spożycie w 2017 r. wzrosło do 30,5 kg na mieszkańca a w br. wzrośnie do 30,8 kg na mieszkańca (Świetlik 2018).

\section{Przegląd literatury}

Zdecydowana większość wyników badań poświęconych polskiemu rynkowi drobiu dotyczy cen (np. Utnik-Banaś, 2012; Hamulczuk i in., 2012; Hamulczuk, 2013; Świetlik, 2008; Czyżewski i in., 2008; Kłusek, 2015), spożycia (Świetlik, 2008; Konarska i in., 2015), produkcji drobiu lub całego sektora (np. Utnik-Banaś, 2016; Dybowski, 2014; Pasińska, 2016; Czakowski, 2015). Te, które są poświęcone handlowi zagranicznemu dotyczą zwykle analizy handlu drobiu domowego ogółem (np. Dybowski, 2016) mięsa i podrobów drobiowych ogółem (np. Czyżewski i in., 2008; Utnik-Banaś, 2016) lub mięsa kurzego (np. Utnik-Banaś, 2016). Ponadto badania dotyczące kierunków geograficznych handlu zagranicznego produktami drobiowymi prowadzi Instytut Ekonomiki Rolnictwa i Gospodarki Żywnościowej - Państwowy Instytut Badawczy. Głównym celem badań prowadzonych przez Instytut jest ocena krótkookresowych zmian na rynku drobiu w Polsce. Wyniki tych badań publikowane są dwa razy w roku (IERiGŻ-PIB 2012-2018). W wymienionych opracowaniach brak jest analizy skali polskiego handlu zagranicznego produktami kurzymi tj. drobiem żywym kurzym, mięsem i podrobami czy przetworami kurzymi.

\section{Dane i metody}

Głównym celem opracowania jest przedstawienie polskiego rynku kurzego w latach 2012-2017 w kontekście zmian w handlu zagranicznym produktami kurzymi, tj. żywcem, mięsem i podrobami oraz przetworami kurzymi. Przyjęto hipotezę badawczą, że z Polski eksportuje się coraz więcej produktów kurzych, a import zmniejsza się, z czego wynika potrzeba ustalenia rozmiarów handlu zagranicznego tymi produktami. Zasadniczą metodą służącą do realizacji hipotezy jest analiza porównawcza w czasie (przyrosty względne oraz wskaźniki dynamiki o podstawie stałej i łańcuchowej) pogłowia brojlerów kurzych wg skali chowu, ubojów, eksportu i importu ogółem i poszczególnych grup produktowych oraz analiza struktury towarowej eksportu i importu produktów kurzych, a także oszacowanie liniowej funkcji trendu dla eksportu $(\widehat{E})$ i importu $(\hat{I})$. Oszacowanie dla eksportu przedstawia się następująco:

$$
\widehat{E}=123,55 t+249,9
$$

a dla importu:

$$
\hat{I}=12,957 t+61,053
$$

gdzie:

$t-$ okres, $t=1,2, \ldots, 6$. 
Otrzymane rezultaty badawcze są ważne dla producentów rolnych, przetwórców, detalistów, hurtowników, gastronomii oraz dla polityki gospodarczej państwa. Badania te mogą być wsparciem dla przedsiębiorstw, którzy chcą określić swoją pozycję konkurencyjną na rynku (np. mogą ustalić swój udział w eksporcie określonych grup asortymentowych) czy dla producentów rolnych - w podjęciu decyzji o rozszerzaniu bądź ograniczeniu skali działania. W badaniach wykorzystano dane roczne Ministerstwa Finansów z lat 2012-2017, korzystano również z danych Głównego Urzędu Statystycznego. Dane dotyczące handlu zagranicznego za 2017 r. są danymi wstępnymi. Odstępstwa od wskazanego zakresu czasowego wynikały przede wszystkim z braku dostępu do danych.

\section{Tendencje w produkcji żywca kurzego w Polsce}

W badanym okresie uboje drobiu w Polsce rosły. W 2017 r. w porównaniu z 2012 r. uboje drobiu kurzego zwiększyły się o prawie 59\% do 2736,4 tys. ton wagi żywej (rys. 1). W latach 2012-2017 udział drobiu kurzego w ubojach drobiu domowego ogółem wahał się w przedziale od $81 \%$ do $83 \%$.

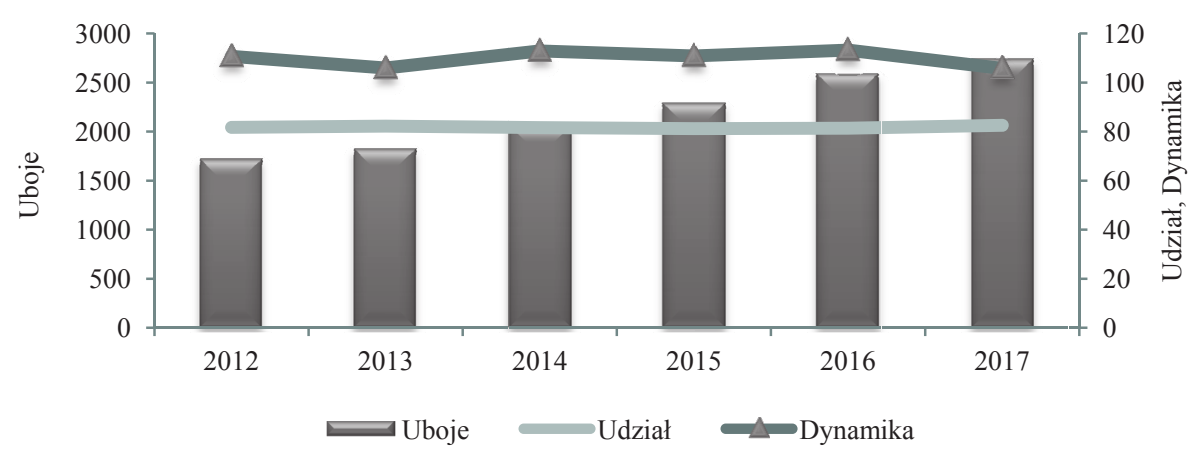

Rys. 1. Uboje przemysłowe drobiu kurzego (w tys. ton wagi żywej), udział ubojów przemysłowych żywca kurzego w ubojach żywca drobiowego ogółem (w \%), zmiany ubojów przemysłowych żywca kurzego - rok poprzedni $=100(\mathrm{w} \%)$.

Fig. 1. Industrial slaughter of chicken poultry (in thousands of tonnes live weight), the share of slaughtered chicken in slaughtered poultry in slaughterhouses (in \%), changes in slaughter of chicken livestock - previous year $=100$ (in \%).

Źródło: opracowanie własne (GUS c, 2013, .., 2018).

Produkcja kurcząt brojlerów w Polsce jest bardzo skoncentrowana, w 2016 r. 97,9\% (wobec 93,7\% w 2013 r.) pogłowia brojlerów było utrzymywanych w stadach liczących 10 tys. i więcej sztuk przez zaledwie 3,8\% (wobec 2,8\%) gospodarstw zajmujących się chowem brojlerów kurzych (GUS a 2014 2017) (rys. 2). Prawie 96\% gospodarstw utrzymywało w stadach liczących od 1 do 99 sztuk 1,1\% pogłowia. W 2016 r. w porównaniu z 2013 r. wzrosła przeciętna liczba brojlerów kurzych przypadających na jedno gospodarstwo do 1968 szt. (wobec 1156 szt.) (GUS a, 2017). 

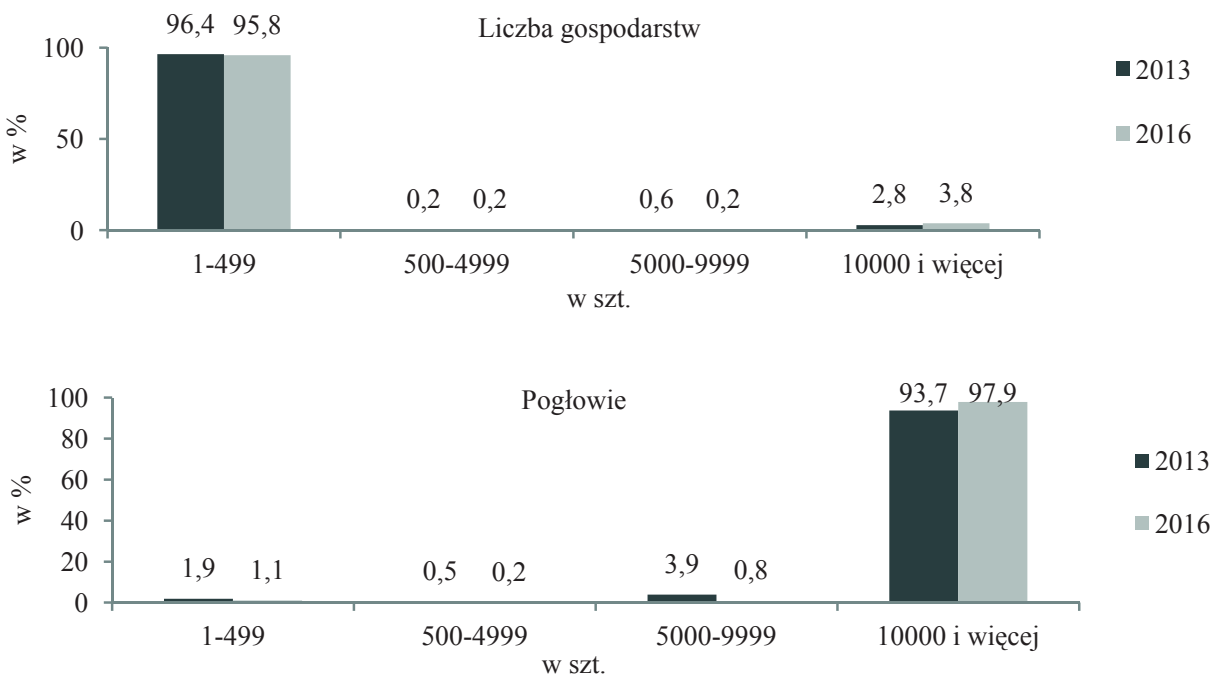

Rys. 2. Struktura pogłowia kurcząt brojlerów wg skali chowu w 2013 r. i 2016 r. (w \%) (od 1 szt. do 10000 szt. i więcej)

Fig. 2. Structure of the broiler chicken stock according to the rearing scale in 2013 and 2016 (in \%) (from 1 to 10000 items and more)

Źródło: opracowanie własne na podstawie: (GUS a 2014, 2017).

W 2016 r. chowem brojlerów kurzych w Polsce zajmowało się 64,5 tys. gospodarstw (wobec 65,4 tys. W 2013 r.). Udział gospodarstw tego typu w ogóle gospodarstw utrzymujących zwierzęta gospodarskie wynosił 9\% (wobec 8,2\% w 2013 r.) (GUS a 2014, 2017).

\section{Handel zagraniczny produktami kurzymi}

W latach 2012-2017 polskie obroty handlu zagranicznego produktami kurzymi wykazywały tendencję wzrostową (rys. 3). W ujęciu względnym średnioroczne tempo wzrostu eksportu produktów kurzych wyniosło 19,4\%. Na podstawie oszacowanej liniowej funkcji trendu, dla eksportu produktów kurzych można stwierdzić, że z roku na rok eksport rósł o 123,5 tys. ton. Za pomocą skonstruowanego równania udało się objaśnić 98\% zmienności eksportu. Eksport ogółem (żywca, mięsa i podrobów oraz przetworów kurzych) wzrósł ponad 2-krotnie z 419 tys. ton w 2012 r. do 1017 tys. ton w 2017 roku, przy jednoczesnym wzroście importu (o 83\%) (zob. tab. 1). Polska była eksporterem netto produktów kurzych w całym badanym okresie. Zwiększenie wolumenu wywozu było wypadkową zwiększenia eksportu drobiu kurzego żywego o 17\%, mięsa i podrobów o $137 \%$ i przetworów o 229\%. Było ono możliwe dzięki znacznemu wzrostowi produkcji żywca kurzego. W latach 2013-2017 eksport mięsa i podrobów oraz przetworów kurzych wzrastał, natomiast eksport drobiu żywego rósł tylko w latach 2013-2016, a w 2017 r. spadł, co najprawdopodobniej miało związek z wystąpieniem ptasiej grypy w Polsce na przełomie 2016 r. i 2017 r. 


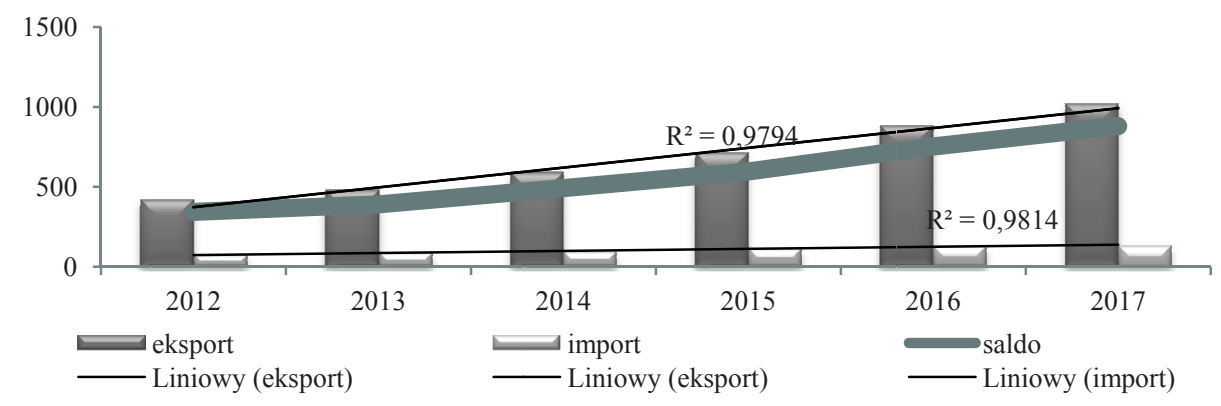

Rys. 3. Polski handel zagraniczny produktami kurzymi w latach 2012-2017 (w tys. ton)

Fig. 3. Polish foreign trade in chicken products in 2012-2017 (in thousands of tons)

Źródło: Opracowanie własne na podstawie danych Ministerstwa Finansów.

W badanym okresie import produktów kurzych wyrażony w ujęciu ilościowym wzrósł o prawie $83 \%$, zaś w ujęciu wartościowym o $84 \%$ do niemal $173 \mathrm{mln}$ EUR. Wzrost wolumenu importu był wypadkową wzrostu przywozu drobiu kurzego żywego o 104\%, mięsa i podrobów kurzych o $68 \%$ i przetworów o 2\% (zob. rys. 3 i tab. 1). Pomimo tego, że wolumen importu produktów kurzych wzrósł w 2017 r. w porównaniu do 2012 r., w poszczególnych grupach produktowych występowały również jego spadki tj. mięsa i podrobów kurzych w 2013 r. (o 9\%), drobiu żywego w 2017 r. (o 2\%), przetworów w 2014 r. i 2015 r. (odpowiednio o 22\% i 5\%). Na podstawie oszacowanej liniowej funkcji trendu można stwierdzić, że import rósł z okresu na okres o 12,9 tys. ton. Za pomoca skonstruowanego równania udało się objaśnić 98\% zmienności importu. Import ten W szczególności w relacji do polskiego eksportu produktów kurzych był niewielki. Przywóz do Polski w latach 2012-2017 rósł średnio z roku na rok o 12,8\%.

Tabela 1. Zmiany wolumenu eksportu i importu produktów kurzych w latach 2013-2017 (w \%)

Table 1. Changes in the volume of export and import of chicken products in the years 2013-2017 (in \%)

\begin{tabular}{|c|c|c|c|c|c|c|}
\hline \multirow{2}{*}{ Wyszczególnienie } & 2013 & 2014 & 2015 & 2016 & 2017 & 2017 \\
\hline & \multicolumn{5}{|c|}{ rok poprzedni $=100$} & $2012=100$ \\
\hline & \multicolumn{6}{|c|}{ eksport } \\
\hline ogółem & 114 & 122 & 121 & 124 & 115 & 243 \\
\hline drób kurzy żywy & 101 & 112 & 178 & 141 & 41 & 117 \\
\hline mięso i podroby & 113 & 123 & 119 & 125 & 114 & 237 \\
\hline przetwory & 128 & 113 & $\begin{array}{c}142 \\
\mathrm{im}\end{array}$ & 113 & 142 & 329 \\
\hline ogółem & 118 & 107 & 120 & 114 & 105 & 183 \\
\hline drób kurzy żywy & 132 & 113 & 126 & 110 & 98 & 204 \\
\hline mięso i podroby & 91 & 101 & 111 & 131 & 126 & 168 \\
\hline przetwory & 120 & 78 & 95 & 110 & 103 & 102 \\
\hline
\end{tabular}

Źródło: opracowanie własne na podstawie danych Ministerstwa Finansów.

W latach 2012-2017 udział eksportu poszczególnych grup produktowych kurzych w eksporcie poszczególnych grup produktowych drobiowych ogółem był zróżnicowany, 
najwyższy w przypadku mięsa i podrobów drobiowych (od prawie 73\%) i przetworów kurzych (od prawie 63\%), mniejszy zaś dla drobiu żywego (od 16\% do 30\%) (tab. 2). Udział importu żywego drobiu kurzego w imporcie żywego drobiu ogółem wahał się w przedziale od $73 \%$ do $85 \%$, mięsa i podrobów kurzych w mięsie drobiowym ogółem - od $53 \%$ do $69 \%$, przetworów kurzych - od $86 \%$ do $96 \%$.

Tabela 2. Udział eksportu (importu) poszczególnych grup produktowych kurzych w eksporcie (imporcie) poszczególnych grup produktowych drobiowych ogółem (w \%)

Table 2. The share of export (import) of individual chicken product groups in the export (import) of individual poultry product groups in total (in \%)

\begin{tabular}{l|cccccc}
\hline \multicolumn{1}{c}{ Wyszczególnienie } & 2012 & 2013 & 2014 & 2015 & 2016 & 2017 \\
\hline \multirow{2}{*}{ drób kurzy żywy } & 23 & 16 & 17 & 28 & 30 & 17 \\
mięso i podroby & 73 & 74 & 75 & 75 & 78 & 82 \\
przetwory & 63 & 65 & 66 & 75 & 78 & 84 \\
& & & eksport & & \\
drób kurzy żywy & 85 & 82 & 73 & 80 & 81 & 81 \\
mięso i podroby & 53 & 53 & 57 & 66 & 66 & 69 \\
przetwory & 86 & 89 & 87 & 87 & 88 & 96 \\
\hline
\end{tabular}

Źródło: opracowanie własne na podstawie danych Ministerstwa Finansów.

W latach 2012-2017 struktura towarowa polskiego eksportu produktów kurzych była zróżnicowana. W strukturze towarowej dominowało mięso i podroby kurze (o udziale wahającym się od 90\% do 92\%) (tab. 3). W 2017 r. w strukturze eksportu mięsa i podrobów kurzych najpopularniejszymi elementami były:

- zamrożone kawałki bez kości,

- $\quad$ świeże lub schłodzone kawałki bez kości,

- $\quad$ zamrożone całe skrzydła, z końcami lub bez.

Mięso i podroby kurze eksportowane z Polski nabywały głównie kraje UE. W badanym okresie zmieniały się pozycje zajmowane przez głównych odbiorców w eksporcie. W 2012 r. najwięcej mięsa i podrobów eksportowano do: Czech, Wielkiej Brytanii, Niemiec, Holandii, Słowacji, Francji, Bułgarii i Litwy, a w 2017 r. - do: Niemiec, na Ukrainę, do Wielkiej Brytanii, Holandii, Francji, Czech i Bułgarii. Relatywnie mały udział $\mathrm{w}$ wywozie miały pozostałe grupy produktowe tj. przetwory drobiowe (od $7 \%$ do 10\%), żywiec drobiowy (do 1\%). W latach 2012-2017 wśród zagranicznych nabywców przetworów kurzych eksportowanych z Polski dużym zainteresowaniem cieszyły się:

- mięso lub podroby przetworzone lub zakonserwowane, poddane obróbce cieplnej, zawierające więcej bądź równo 57\% masy mięsa lub podrobów drobiowych (oprócz kiełbas i podobnych wyrobów, drobno homogenizowanych przetworów, pakowanych do sprzedaży detalicznej jako żywność dla niemowląt lub do celów dietetycznych, w pojemnikach o zawartości netto mniejszej bądź równej $250 \mathrm{~g}$ masy, przetworów z wątroby (wątróbki), i ekstraktów z mięsa),

- mięso lub podroby $\mathrm{z}$ ptactwa przetworzone lub zakonserwowane, niepoddane obróbce cieplnej, zawierające więcej bądź równo 57\% masy mięsa lub podrobów 
drobiowych (oprócz kiełbas i podobnych wyrobów, i przetworów z wątroby (wątróbki)) (dane MF).

W strukturze ilościowej (sztuki) wywożonego żywca kurzego największy udział miały pisklęta kurze (dane MF).

Tabela 3. Udział eksportu (importu) poszczególnych grup produktowych kurzych w eksporcie (imporcie) produktów kurzych ogółem (w \%)

Table 3. The share of export (import) of individual chicken product groups in the export (import) of chicken products in total (in \%)

\begin{tabular}{l|cccccc}
\hline \multicolumn{1}{c|}{ Wyszczególnienie } & 2012 & 2013 & 2014 & 2015 & 2016 & 2017 \\
\hline \multirow{2}{*}{ drób kurzy żywy } & \multicolumn{7}{c}{ eksport } \\
mięso i podroby & 0,01 & 0,01 & 0,01 & 0,01 & 0,01 & 0,00 \\
przetwory & 0,92 & 0,91 & 0,92 & 0,90 & 0,91 & 0,90 \\
& 0,07 & 0,08 & 0,07 & 0,09 & 0,08 & 0,10 \\
drób kurzy żywy & 0,59 & 0,66 & 0,70 & 0,73 & 0,70 & 0,66 \\
mięso i podroby & 0,31 & 0,24 & 0,23 & 0,21 & 0,24 & 0,29 \\
przetwory & 0,10 & 0,10 & 0,07 & 0,06 & 0,06 & 0,06 \\
\hline
\end{tabular}

Źródło: opracowanie własne na podstawie danych Ministerstwa Finansów

Struktura towarowa polskiego importu produktów kurzych była zróżnicowana i zmieniała się w analizowanym okresie (tab. 3). Udział drobiu żywego w imporcie wzrósł z 59\% w 2012 r. do 66\% w 2017 r., przy jednoczesnym spadku udziału przetworów z 10\% do $6 \%$ oraz mięsa i podrobów kurzych z $31 \%$ do $29 \%$. W ostatnich latach ponad połowę importowanych sztuk stanowił drób kurzy o masie nie przekraczającej 185 g, a wśród mięsa i podrobów największe udziały miały w 2012 r.:

- $\quad$ kawałki z kośćmi, świeże lub schłodzone (oprócz połówek lub ćwiartek, całych skrzydeł, nawet z końcami, grzbietów, szyj, grzbietów włącznie z szyjami, kuprów i końców skrzydeł, piersi, nóg i ich kawałków),

- kawałki bez kości, zamrożone,

- $\quad$ grzbiety, szyje, grzbiety włącznie z szyjami, kupry i końce skrzydeł, świeże lub schłodzone

a w 2017 r.:

- kawałki bez kości, zamrożone,

- kawałki bez kości, świeże lub schłodzone,

- $\quad$ kawałki z kośćmi, świeże lub schłodzone (oprócz połówek lub ćwiartek, całych skrzydeł, nawet z końcami, grzbietów, szyj, grzbietów włącznie z szyjami, kuprów i końców skrzydeł, piersi, nóg i ich kawałków) (dane MF).

W latach 2012-2017 mięso i podroby kurze importowano przede wszystkim z krajów UE, choć jej udział zmniejszył się z 99,9\% w 2012 r. do 91,1\% w 2017 r.. W 2012 r. największymi dostawcami mięsa i podrobów kurzych były: Holandia, Niemcy, Wielka Brytania, Węgry, a w 2017 r. - Niemcy, Wielka Brytania, Słowacja i Ukraina, której udział w polskim imporcie mięsa i podrobów kurzych wynosił aż 8,0\%. W badanym okresie największe udziały wśród importowanych przetworów kurzych miały: 
- mięso lub podroby przetworzone lub zakonserwowane, poddane obróbce cieplnej, zawierające więcej bądź równo $57 \%$ masy mięsa lub podrobów drobiowych (oprócz kiełbas i podobnych wyrobów, drobno homogenizowanych przetworów, pakowanych do sprzedaży detalicznej jako żywność dla niemowląt lub do celów dietetycznych, w pojemnikach o zawartości netto mniejszej bądź równej $250 \mathrm{~g}$ masy, przetworów z wątroby (wątróbki), i ekstraktów z mięsa),

- mięso lub podroby przetworzone lub zakonserwowane, zawierające więcej bądź równo $25 \%$, ale mniej niż $57 \%$ masy mięsa lub podrobów drobiowych (oprócz kiełbas i podobnych wyrobów, drobno homogenizowanych przetworów, pakowanych do sprzedaży detalicznej jako żywność dla niemowląt lub do celów dietetycznych, w pojemnikach o zawartości netto mniejszej bądź równo $250 \mathrm{~g}$ masy, przetworów z wątroby (wątróbki), i ekstraktów z mięsa) (dane MF).

W badanym okresie Polska była eksporterem netto mięsa i podrobów ogółem oraz przetworów kurzych (zob. rys. 4). Natomiast w całym badanym okresie saldo obrotu żywcem kurzym było ujemne.
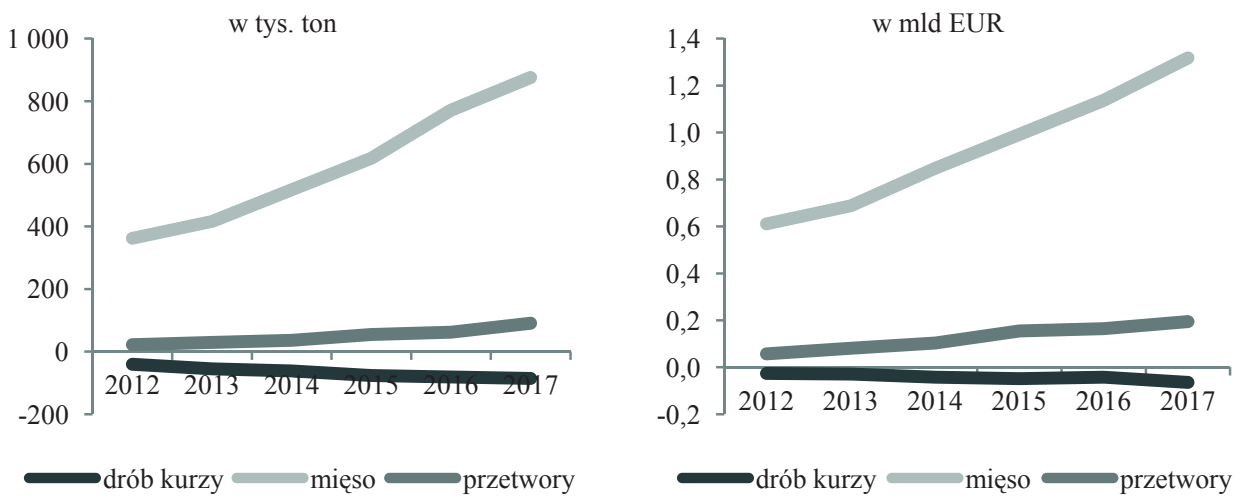

Rys. 4. Salda obrotów handlu zagranicznego produktami kurzymi (w tys. ton i mld EUR)

Fig. 4. Balance of foreign trade in chicken products (in thousands of tons and billion of EUR)

Źródło: opracowanie własne na podstawie danych MF.

W latach 2012-2017 relacje cen tuszek w badanych krajach europejskich do cen takich tuszek w Polsce były zróżnicowane (zob. tab. 4). W niektórych okresach w Niemczech, Danii, na Cyprze, Finlandii i w Szwecji nabywca za kilogram tuszki kurczęcej $65 \%{ }^{2}$ musiał zapłacił dwa razy więcej niż w Polsce. Wśród branych pod uwagę krajów europejskich cena tego rodzaju tuszki w Polsce była prawie najniższa lub najniższa. Analiza relacji cen tuszek ma pewne ograniczenia, bowiem tuszki mogą cechować się różną jakością, posiadać różne certyfikaty bądź nie, pochodzić z różnych systemów chowu (np. ekologicznego, bez antybiotyków) czy cechować się różnym przedziałem czasowym do terminu przydatności.

\footnotetext{
${ }^{2}$ Np. według Wspólnej Taryfy Celnej „kurczaki 65\%” są to niecięte na kawałki tuszki, które są „oskubane i wypatroszone, bez głów i łapek oraz bez szyj, serc, wątróbek i żołądków” (KE 2017).
} 
Tabela 4. Kształtowanie się relacji cen tuszki kurcząt 65\% w wybranych krajach UE do cen w Polsce

Table 4. The development of the chicken carcass price relations $65 \%$ in selected EU countries to prices in Poland

\begin{tabular}{|c|c|c|c|c|c|c|}
\hline Wyszczególnienie & 2012 & 2013 & 2014 & 2015 & 2016 & 2017 \\
\hline Belgia & 1,29 & 1,29 & 1,29 & 1,34 & 1,40 & 1,33 \\
\hline Bułgaria & 1,13 & 1,14 & 1,12 & 1,17 & 1,22 & 1,18 \\
\hline Czechy & 1,32 & 1,38 & 1,34 & 1,43 & 1,50 & 1,45 \\
\hline Dania & 1,79 & 1,83 & 1,85 & 1,92 & 2,01 & 1,94 \\
\hline Niemcy & 1,79 & 1,86 & 1,95 & 2,03 & 2,24 & 2,16 \\
\hline Estonia & (.) & 1,29 & 1,34 & 1,40 & 1,47 & 1,31 \\
\hline Irlandia & 1,28 & 1,28 & 1,32 & 1,41 & 0,93 & 0,78 \\
\hline Grecja & 1,45 & 1,47 & 1,47 & 1,57 & 1,74 & 1,64 \\
\hline Hiszpania & 1,32 & 1,30 & 1,28 & 1,32 & 1,35 & 1,33 \\
\hline Francja & 1,61 & 1,64 & 1,62 & 1,73 & 1,90 & 1,84 \\
\hline Chorwacja & (.) & 1,39 & 1,37 & 1,43 & 1,52 & 1,48 \\
\hline Włochy & 1,59 & 1,69 & 1,65 & 1,60 & 1,55 & 1,65 \\
\hline Cypr & 1,80 & 1,83 & 1,90 & 1,99 & 2,14 & 2,04 \\
\hline Lotwa & 1,26 & 1,28 & 1,30 & 1,28 & 1,31 & 1,30 \\
\hline Litwa & 1,11 & 1,10 & 1,08 & 1,16 & 1,19 & 1,16 \\
\hline Węgry & 1,16 & 1,19 & 1,19 & 1,20 & 1,20 & 1,17 \\
\hline Malta & 1,49 & 1,59 & 1,63 & 1,73 & 1,89 & 1,79 \\
\hline Holandia & 1,40 & 1,43 & 1,51 & 1,53 & 1,53 & 1,38 \\
\hline Austria & 1,37 & 1,40 & 1,44 & 1,44 & 1,54 & 1,46 \\
\hline Polska & 1,00 & 1,00 & 1,00 & 1,00 & 1,00 & 1,00 \\
\hline Portugalia & 1,21 & 1,19 & 1,16 & 1,21 & 1,16 & 1,24 \\
\hline Rumunia & 1,19 & 1,24 & 1,22 & 1,17 & 1,24 & 1,19 \\
\hline Słowenia & 1,44 & 1,48 & 1,47 & 1,56 & 1,62 & 1,55 \\
\hline Słowacja & 1,36 & 1,42 & 1,32 & 1,34 & 1,32 & 1,21 \\
\hline Finlandia & 1,83 & 1,92 & 1,95 & 2,04 & 2,16 & 2,05 \\
\hline Szwecja & 1,72 & 1,77 & 1,77 & 1,96 & 2,23 & 1,99 \\
\hline Wielka Brytania & 1,08 & 1,08 & 1,20 & 1,37 & 1,30 & 1,20 \\
\hline EU & 1,36 & 1,38 & 1,40 & 1,46 & 1,50 & 1,46 \\
\hline
\end{tabular}

Źródło: opracowanie własne na podstawie: (Weekly 2018).

W latach 2012-2017 średnie ceny eksportowanych z Polski tuszek kurcząt $65 \%{ }^{3}$ były zróżnicowane (zob. rys. 5). W latach 2012-2017 średnie ceny schłodzonych tuszek kurcząt $65 \%$ eksportowanych z Polski były zbliżone do średnich cen takich tuszek eksportowanych z Polski do UE, natomiast średnie ceny takich tuszek eksportowanych do krajów niebędących członkami UE (krajów trzecich) były niższe od cen tuszek eksportowanych do UE w latach 2012-2015, a w latach 2016-2017 - wyższe. W latach 2012-2017 średnie ceny mrożonych tuszek kurcząt $65 \%$ eksportowanych do krajów trzecich były niższe od średnich cen takich tuszek eksportowanych do krajów będących członkami UE.

Polski sektor kurcząt brojlerów jest jednym z najnowocześniejszych na świecie. Niewattpliwie wstapienie Polski do Unii Europejskiej spowodowało konieczność dostosowania sektora i przemysłu do bardzo wysokich wymogów weterynaryjnych czy dobrostanu zwierząt, w rezultacie polski drób posiada przewagę w porównaniu z krajami niebędącymi członkami UE.

\footnotetext{
${ }^{3}$ lub inaczej zgłaszane.
} 


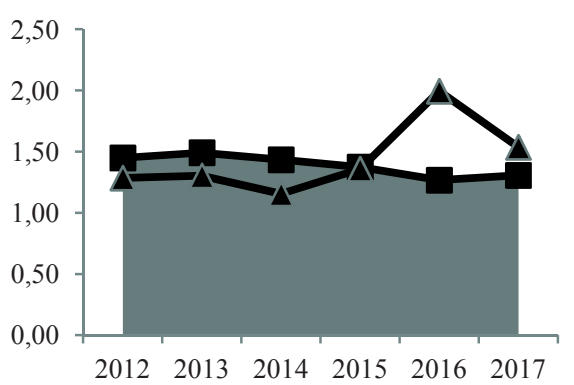

cena schłodzonej tuszki 65\% eksportowanej z Polski

- cena schłodzonej tuszki $65 \%$ eksportowanej do UE

- cena schłodzonej tuszki 65\% eksportowanej poza UE

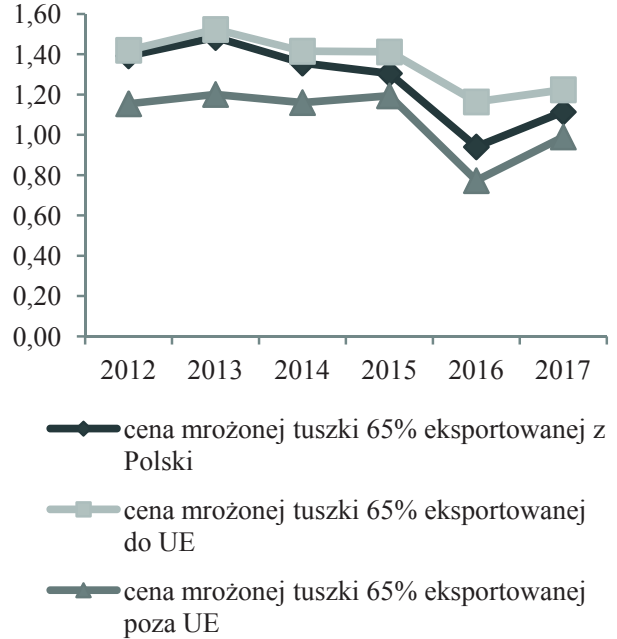

Rys. 5. Średnia cena eksportowa (z Polski) tuszki kurcząt schłodzonej i mrożonej 65\% (ogółem - z Polski, do krajów UE i do krajów nie będących członkami UE) w EUR/kg

Fig. 5. Average export price (from Poland) of chilled and frozen chicken carcasses $65 \%$ (in total, to EU countries and to non-EU countries) in EUR/kg

Źródło: opracowanie własne na podstawie danych MF.

\section{Głos w dyskusji}

Do zwiększenia polskiego eksportu produktów kurzych może się przyczynić: dywersyfikacja kierunków geograficznych eksportu, przewaga cenowa polskich produktów kurzych na rynku UE i światowym, a przy tym odpowiednia ich jakość. Polski drób kurzy posiada przewagę cenową na rynku unijnym, nie jest jednak najtańszy na świecie. Dlatego też należy monitorować działania konkurentów oferujących tani drób np. kraje Mercosur, z którymi najprawdopodobniej zostanie zawarta umowa o wolnym handlu ${ }^{4}$. Jednym z głównych nabywców polskiego drobiu jest Wielka Brytania, jej wyjście z UE może wpłynąc na sytuację sektora (w zależności od ustalonych warunków tego wyjścia). Udział Ukrainy w imporcie mięsa i podrobów drobiowych w 2017 r. wynosił 8\%, jeśli kraj ten będzie zwiększał eksport na polski rynek i inne rynki zbytu polskiego drobiu, uwarunkowania dla polskiego handlu zagranicznego mogą pogorszyć się.

Zachodzą zmiany na rynkach produktów substytucyjnych. Rynek produktów wegańskich zaczyna w ostatnim czasie rozwijać, pojawiają się również inne konkurencyjne produkty zawierające np. białko owadzie. Prowadzone są również prace nad substytutami np. mięsem in vitro. Wciąż wydaje się ważne szukanie produktów niszowych i innowacyjnych (np. kurczaki karmione w określony, specyficzny sposób, ekologiczne).

\footnotetext{
${ }^{4}$ Brazylia dysponuje ogromną nadwyżką podaży mięsa drobiowego. Ma bardzo dobre warunki klimatyczne (np. nie trzeba budować ogrzewanych kurników), technologiczne (np. duża podaż kukurydzy i soi) i ekonomiczne (np. tania siła robocza) do rozwoju produkcji drobiu kurzego (Dybowski 2016).
} 
Salda obrotu różnymi grupami produktowymi z krajami trzecimi ogółem były dodatnie. Eksport produktów kurzych do krajów trzecich był niewielki między innymi z powodu trudności w oferowaniu produktów o smakach zbliżonych do lokalnych, a także z powodu silnej konkurencji ze strony producentów oferujących niższe ceny bądź mających już nawiązane trwałe relacje handlowe.

Ocenia się, że w najbliższych kilku latach zarówno eksport produktów kurzych jak i produkcja żywca kurzego utrzyma się na relatywnie wysokim poziomie, co więcej Polska najprawdopodobniej nadal będzie głównym producentem mięsa kurzego w UE (jeśli nie wystąpią poważne zakłócenia na rynku np. ptasia grypa). Większa podaż żywca kurzego na rynku krajowym i unijnym może być źródłem presji spadkowej na ceny, choć do jej wyhamowania najprawdopodobniej przyczyni się przyrost liczby ludności na świecie oraz wzrost dochodów rozporządzalnych. Wielu producentów będzie inwestować w kolejne kurniki, czemu będą towarzyszyć procesy integracji pionowej i poziomej. Można rozważyć w kontekście efektywności ekonomicznej i bezpieczeństwa żywnościowego uniezależnienie od importowanych piskląt i jaj kurzych wylęgowych. Popyt na mięso kurze może znacznie wzrosnąć w przypadku wystąpienia globalnego kryzysu finansowego, w szczególności w krajach o relatywnie niskich dochodach rozporządzalnych na osobę.

\section{Podsumowanie}

Obecnie Polska jest samowystarczalna w produkcji mięsa kurzego, a znaczna część tej produkcji jest eksportowana, głównie do krajów UE. W latach 2012-2017 obserwowano wzrost eksportu i importu produktów kurzych. W badanym okresie udział eksportu mięsa i podrobów kurzych w wywozie mięsa i podrobów drobiowych był znaczny (powyżej $70 \%$ ). Udział ten nadal będzie relatywnie wysoki, a będzie to rezultatem niskiej ceny mięsa kurzego w porównaniu z mięsami z innych popularnych gatunków zwierząt, przyzwyczajeń i nawyków w jego spożyciu (czemu sprzyja jego łatwa obróbka kulinarna) oraz większej neutralności religijnej $\mathrm{w}$ porównaniu $\mathrm{np}$. $\mathrm{z}$ wieprzowiną. $\mathrm{W}$ badanym okresie struktura importu była odmienna w porównaniu ze strukturą eksportu, największy udział w imporcie miał drób kurzy żywy.

W latach 2012-2017 Polska była eksporterem netto mięsa i podrobów, przetworów kurzych oraz importerem netto żywca kurzego. Dynamicznym zmianom eksportu towarzyszyły: dosyć zaawansowane i wciąż postępujące procesy koncentracji chowu żywca kurzego oraz zmienna opłacalność jego chowu. Spośród mięs drobiowych, mięso kurze miało największy udział w spożyciu.

W badanym okresie relacje cen tuszek kurcząt w różnych krajach europejskich do cen takich tuszek w Polsce były zróżnicowane, choć polskie tuszki były najtańsze lub prawie najtańsze. Przewiduje się, że relacje te w najbliższych kilku latach nie zmienią się znacznie.

\section{Literatura}

Czakowski, D. (2015). Zasobowe i efektywnościowe uwarunkowania produkcji drobiu i jaj w Polsce z perspektywy akcesji do Unii Europejskiej (Resource and efficiency conditions for the production of poultry and eggs in Poland from the perspective of accession to the European Union). Roczniki Naukowe Stowarzyszenia Ekonomistów Rolnictwa i Agrobiznesu, 17(2), 20-25.

Czyżewski, A., Danilczuk, J. (2008). Konkurencyjność polskiego rynku drobiu i jaj w wymianie z Unią Europejską (Competitiveness of the Polish poultry and eggs market in exchange with the European Union). Roczniki Naukowe Stowarzyszenia Ekonomistów Rolnictwa i Agrobiznesu, 10(4), 56-61. 
Dybowski, G. (2016). Rynek mięsa drobiowego (The market for poultry meat) W: S. Stańko (red.), Sytuacja na światowych rynkach mięsa i produktów mleczarskich oraz jej wpływ na rynek krajowy i możliwości jego rozwoju (The situation on the world markets of meat and dairy products and its impact on the domestic market and the possibilities of its development), Warszawa: IERiGŻ-PIB, 79-104.

Dybowski, G. (2014). Podstawy konkurencyjności polskiej branży drobiarskiej (The basis of competitiveness of the Polish poultry industry), Warszawa: IERiGŻ-PIB

GUS a. 2014, 2017, Charakterystyka gospodarstw rolnych w 2013 r., ..., 2016 r. (Characteristics of agricultural holdings in $2013, \ldots . ., 2016)$, Warszawa.

GUS b. (2013-2017). Rynek wewnętrzny w 2012 r. ... 2016 r. (Internal market in 2012 ... 2016). Warszawa.

GUS c. (2013-2018). Zwierzęta gospodarskie w 2012 r. ... 2017 r. (Livestock in 2012 ... 2017). Warszawa.

Hamulczuk, M., Gędek, S., Klimkowski, C. Stańko, S. (2012). Prognozowanie cen surowców rolnych na podstawie zależności przyczynowych (Forecasting the prices of agricultural commodities on the basis of causal relationships), Warszawa: IERiGŻ-PIB.

Hamulczuk, M. (2013). Asymetria w transmisji cen w łańcuchu żywnościowym. Przykład cen drobiu w Polsce (Asymmetry in price transmission in the food chain. Example of poultry prices in Poland) W: J. Sokołowski, G. Węgrzyn (red.). Polityka ekonomiczna, Wrocław: Wydawnictwo UE we Wrocławiu, 212-223.

IERiGŻ-PIB, MRiRW, KOWR (ARR), (2012-2018), Rynek drobiu (i jaj) - stan i perspektywy (Poultry market (and of eggs) - the state and prospects), $\mathrm{nr} 42-53$.

KE (2017). Rozporządzenie wykonawcze Komisji (UE) 2017/1925 z dnia 12 października 2017 r. zmieniające załącznik I do rozporządzenia Rady (EWG) nr 2658/87 w sprawie nomenklatury taryfowej i statystycznej oraz w sprawie Wspólnej Taryfy Celnej (Commission Implementing Regulation (EU) 2017/1925 of 12 October 2017 amending Annex I to Council Regulation (EEC) No 2658/87 on the tariff and statistical nomenclature and on the Common Customs Tariff).

Kłusek, K. (2015). Zmiany cen tuszek kurczaków w wybranych krajach Unii Europejskiej w latach 2009-2015 (Price changes of chicken carcasses in selected European Union countries in 2009-2015). Problemy Rolnictwa Światowego, 15(3), 61-69.

Konarska, M., Sakowska, A., Przybysz, M., Popis, E. (2015). Produkcja i spożycie mięsa drobiowego na świecie i w Polsce w latach 2000-2014 (Production and consumption of poultry meat in the world and in Poland between 2000-2014). Problemy Rolnictwa Światowego, 15(2), 96-105.

Pasińska, D. (2016). Polski rynek drobiu po wstapieniu do Unii Europejskiej (Polish poultry market after the accession to the European Union). Polityka Ekonomiczna, 421-432.

Slaughtering in slaughterhouses - annual data (2018). Pobrane 11 czerwca 2018 z: http://appsso.eurostat.ec. europa.eu/nui/setupDownloads.do.

Świetlik, K. (2008). Ceny żywności w procesie rynkowych przemian polskiej gospodarki (1994-2004) (Food prices in the process of market changes in the Polish economy (1994-2004)), Warszawa: IERiGŻ-PIB.

Świetlik, K. (2018). Spożycie drobiu (Consumption of poultry). Rynek drobiu: stan i perspektywy, 53, 23-29.

Utnik-Banaś, K.(2016). Efektywność produkcji żywca kurcząt brojlerów w okresie przemian gospodarczych w Polsce (Effectiveness of livestock production of broiler chickens in the period of economic transformation in Poland), Kraków: Wydawnictwo Uniwersytetu Rolniczego w Krakowie.

Utnik-Banaś, K. (2012). Analiza szeregu czasowego cen żywca brojlerów w latach 1991-2011 (Analysis of the time series of broiler animal prices in the years 1991-2011). Metody Ilościowe w Badaniach Ekonomicznych, 13(1), 224-233.

Weekly price report on Broiler carcase in the EU (2018), Pobrane 14 maja $2018 \mathrm{z}$ : https://ec.europa.eu/agriculture/ poultry/presentations_pl

Do cytowania / For citation:

Pasińska D. (2018). Handel zagraniczny produktami kurzymi w latach 2012-2017. Problemy Rolnictwa Światowego, 18(4), 38-49; DOI: 10.22630/PRS.2018.18.4.95

Pasińska D. (2018). Polish Foreign Trade in Chicken Products from 2012-2017 (in Polish). Problems of World Agriculture, 18(4), 38-49; DOI: 10.22630/PRS.2018.18.4.95 